\title{
Wanted: Outstanding Ideas for Improving World Order*
}

\author{
Rodger A. Payne, University of Louisville
}

Fo or more than a decade, the University of Louisville's Department of Political Science has administered the Grawemeyer Award for "Ideas Improving World Order." H. Charles Grawemeyer, a local industrialist and generous philanthropist, endowed an annual $\$ 150,000$ prize to stimulate the recognition, dissemination, and critical analysis of outstanding proposals for improving world order. ${ }^{1}$ Given the intellectually diverse background of winners, and the Award's obvious global reach, these goals have been achieved to no small degree. The prize has already been won by scholars and policy analysts from political science, history, economics, law, medicine, theology, and social psychology. Several political leaders have also been among the winners, as has an independent commission of the United Nations (see table). In all, the first decade of winners impressively included nominees from Australia, Canada, Norway, Russia, and the United States. Even more importantly, the award-winning ideas met lofty standards for originality, feasibility, and potential impact on world order. Past Grawemeyer winners have made significant intellectual contributions on a variety of the most important global concerns, including sustainable development, conflict resolution, nuclear strategy, multilateral peacekeeping, and democratization. As per Mr. Grawemeyer's wishes, the award is granted to those who generate new ideas, and does not reward lifetime accomplishments or heroic achievements.

Unfortunately, in 1998, no prize was awarded. The ad hoc International Jury reported to University of Louisville President John Shumaker that none of the year's nominated works merited special recognition. Since the Grawemeyer Award purports to honor ideas generated during a five-year eligibility period, the
1998 outcome could be interpreted as a dismal signal regarding the state of post cold-war thinking about global affairs. Yet, in truth, only a very small percentage of eligible works are ever nominated for the award and this year's Jury specifically concluded that numerous interesting and potentially meritorious ideas were not in the nominee pool. They attributed the shortage of outstanding submissions in large part to the award's undeserved lack of visibility. Moreover, the concept of world order connotes a variety of meanings that do not fit readily into traditional academic or policy thinking about international relations, foreign policy, comparative politics, security affairs, or even peace studies. This ambiguity apparently causes nominators to overlook potentially viable award candidates. Finally, many otherwise outstanding academic works lack the prescriptive content needed to compete successfully for this prize.

Obviously, these legitimate concerns about the breadth and character of the nominee pool deserve attention. The failure of anyone to win the 1998 prize offers a good reason to rethink the Grawemeyer World Order Award's public status and intellectual purpose. Hopefully, this brief essay will encourage readers to nominate deserving work.

\section{Public Status}

Over the years, the World Order Award has attained a reasonably prestigious level of prominence in some circles, though it certainly deserves a higher profile. For various administrative reasons, mostly tied to the expressed wishes of Mr. Grawemeyer, the award must merely invite, rather than actively solicit, external publicity and nominations. Hundreds of brochures are mailed each year to publishers, think tanks, government agencies, and scholars. Announcements are also posted to various relevant listservs and to the University's web site. Representatives from the Screening Committee also regularly distribute brochures to award managers from publishing companies at major academic conferences. However, almost no other public appeals are extended. As a result of these efforts, numerous requests for information arrive throughout the year and about 35 nominations are annually received from all over the world.

The Award's status in intellectual circles is bolstered by several institutional connections. For example, the American Political Science Association, which was consulted about the Award's genesis, has published articles in recent editions of $P S$ based on the public address delivered by the Award's winner-and graciously agreed to print this essay as well. Additionally, the annual meeting of the International Studies Association has lately included on its program a well-attended roundtable featuring the reigning award recipient and other notable scholars who discuss the winner's ideas. The United States Institute for Peace, the International Peace Research Institute (Oslo), and other organizations have also helped publicize the award by hosting ad hoc presentations at various meetings.

Charles Grawemeyer had high aspirations and wanted to create an award similar in purpose to the Nobel Peace Prize, with a broader focus. Unfortunately, the award is not as well known as the Nobel, nor even the so-called MacArthur Foundation "genius grants." The identity of the latest winner is very unlikely to be revealed on the network evening news or featured prominently in The New York Times, though various mass media outlets, including the Chronicle of Higher Education, occasionally carry stories about the winner. ${ }^{2}$ While the cash 
prize is much larger than for any award given by the American Political Science Association, the Grawemeyer is probably not as wellknown even within this discipline as some of those other honors.

Partly as a result of the award's low profile, most nominations originate from publishers' marketing department representatives. Many potentially viable nominations are never submitted, sometimes even after an inquiry about the award has been made. Even high-quality nominations often lack adequately detailed supporting materials, nominations tend to come only in the year of a work's publication or presentation (despite a five-year eligibility period), and some publishers mechanistically submit virtually all of their newest potentially relevant books while making little effort to distinguish them. Ideally, a larger pool of interesting nominations would emanate from scholars, intellectuals, and policy experts, as well as from book publishers and journal editors.

\section{What Is Meant by "World Order"}

Charles Grawemeyer personally selected the name of this prize so as to welcome entries addressing issues of justice and peace as well as design. Mr. Grawemeyer wanted the award to have a worldwide scope, but he specifically rejected the phrase "international relations." Yet, within the discipline of political science, IR scholars are seemingly the most likely to work on problems concerning "world order." Moreover, since "world order studies" is not a well-established subfield, few scholars likely identify themselves as experts in this area. Consequently, the Grawemeyer Award has no direct affinity to an ensconced intellectual community. Ideas improving world order can and do originate from scholars studying various aspects of international law and organization, global political economy, foreign and security policies, peacemaking, comparative politics, and various other related concerns.

The annual promotional brochure includes a lengthy list of issues con- sidered pertinent by the University of Louisville Screening Committee. This listing constitutes a fairly comprehensive inventory of problems affecting world order. Put simply, a large number of problems investigated by scholars from the various IR and comparative subfields should already feel welcomed in the world order tent. Yet, the range of topics covered in any given nomination pool is surprisingly narrow. Almost every year, a batch of submissions are received on a few popular international relations subtopics. For example, in recent years a fairly large number of nominated books, articles, and speeches have dealt narrowly with standards for military intervention (usually by the United States or UN), the (re)organization of Europe (and NATO), and America's post cold-war roles and responsibilities.

While these fairly traditional IR topics are most likely worth serious consideration, a broader range of topics should be appropriately considered for the Grawemeyer Award. Indeed, the study of "world order" might well be distinguished from the analysis of "international relations" in a number of very important ways. For example, the former would not necessarily focus on interstate activities. A large number of social and economic forces seem to affect contemporary world order (Cox 1996; Barber 1996), including transnational advocacy networks (Keck and Sikkink 1998) and nongovernmental organizations (NGOs) (Willetts 1996). Indeed, these groups and networks might be said now to constitute a "global civil society" or "world civic politics" (Lipschutz 1996; Wapner 1996). Alternatively, an examination of world order could focus on "the clash of civilizations" (Huntington 1996) or the role of skilled individuals in a time of turbulent change (Rosenau 1997), rather than on competition and cooperation among nation-states. World order studies potentially also encompasses a much broader issue agenda than does IR. Instead of centering attention on the role military force and power play in determining outcomes, works on world order might focus on an expansive Grawemeyer Award Winners For
Ideas Improving World Order

1988

Richard E. Neustadt and Ernest R. May

Thinking in Time (Free Press)

1989

Robert O. Keohane

After Hegemony (Princeton University)

1990

Robert Jervis

The Meaning of the Nuclear

Revolution (Cornell University)

1991

Gro Harlem Brundtland, Chair

World Commission on

Environment and Development

Our Common Future (Oxford

University)

1992 (co-winners)

Herman E. Daly and John B. Cobb Jr. For the Common Good (Beacon);

Samuel P. Huntington

The Third Wave (University of Oklahoma)

1993

Donald Harman Akenson

God's Peoples (Cornell University)

1994

Mikhail Gorbachev

"Address at the United Nations"

1995

Gareth Evans

"Cooperative Security and Intra-State Conflict" Foreign Policy

1996

Max Singer and Aaron Wildavsky The Real World Order

(Chatham House)

1997

Herbert C. Kelman

"Interactive Problem-Solving"

(several articles)

role for democratic processes (Held 1995) in achieving legitimate global governance (Frank 1990; Falk 1995). So-called "low" political concerns like environment, natural resources, human rights, or world poverty might also figure more prominently in the study of world order than they do in the study of IR (Felice 1996; Stassen 1998). ${ }^{3}$ 
Unfortunately, over the years too few Grawemeyer World Order nominations have examined answers to problems relating to the world economy, global justice, North-South divisions, the role of NGOs in world affairs, the proliferation of weapons of mass destruction, peculiarities of regional disputes (with the exception of the Middle East), international legal concerns like war crimes or genocide, resolution of protracted conflicts, human rights, terrorism, the dislocations caused by globaliza- tion, or the conventional arms trade. Since two works about the global environment won earlier prizes, few new nominations address that topic either.

\section{Conclusion}

The concept of "world order" is certainly broad enough to allow submission of a wider variety of quality nominations than are currently received. While nominations from the field of international relations are certainly welcome, scholars and policy analysts working on broader social, economic, and political concerns should be better represented in the nominee pool. Since the University of Louisville wants to bestow a $\$ 150,000$ Grawemeyer Award for Ideas Improving World Order in 1999, please consider this essay a nudge to nominate and/or submit praiseworthy ideas. The next deadline for nominations is January 4, 1999.

\section{Notes}

* I am grateful for helpful comments provided by Paul Diehl, Nils Petter Gleditsch, Alice Hashim, Landis Jones, Andrew Scobell, Paul Weber, and Charles Ziegler. Thanks for research assistance are extended to Sophie Maier.

1. Three similar annual awards were created in Education, Religion, and Music Com- position and are administered by appropriate academic units at the University. An award in Psychology is in the works. For more information, see the awards' shared web page (www.louisville.edu/ur/onpi/grawemeyer).

2. The largest amount of national publicity was predictably generated by the visit of former Soviet leader Mikhail Gorbachev.
Unfortunately, the most widely reported story focused on the period he spent without his trousers while they were being cleaned and pressed.

3. In particular, the Screening Committee looks for works that offer and evaluate prescriptive means for addressing problems in these areas.

\section{References}

Barber, Benjamin R. 1996. Jihad vs. McWorld, How Globalism and Tribalism are Reshaping the World. New York: Ballantine.

Cox, Robert W., and Timothy J. Sinclair. 1996. Approaches to World Order. New York: Cambridge University.

Falk, Richard. 1995. On Humane Governance: Toward a New Global Politics. University Park, PA: Penn State University Press.

Felice, William F. 1996. Taking Suffering Seriously: The Importance of Collective Human Rights. Albany: State University of New York Press.

Frank, Thomas M. 1990. The Power of Legitimacy Among Nations. New York: Oxford University Press.
Held, David. 1995. Democracy and the Global Order: From the Modern State to Cosmopolitan Governance. Stanford: Stanford University Press.

Huntington, Samuel P. 1996. The Clash of Civilizations and the Remaking of World Order. New York: Touchstone.

Keck, Margaret E., and Kathryn Sikkink. 1998. Activists Beyond Borders: Advocacy Networks in International Politics. Ithaca: Cornell University Press.

Lipschutz, Ronnie D., and Judith Mayer. 1996. Global Civil Society and Global Environmental Governance: The Politics of Nature from Place to Planet. Albany: State University of New York Press.
Rosenau, James N. 1997. Along the DomesticForeign Frontier: Exploring Governance in a Turbulent World. New York: Cambridge University Press.

Stassen, Glen, ed. 1998. Just Peacemaking. Ten Practices for Abolishing War. Cleveland: Pilgrim.

Wapner, Paul. 1996. Environmental Activism and World Civic Politics. Albany: State University of New York Press.

Willetts, Peter, ed. 1996. "The Conscience of the World": The Influence of Non-Governmental Organisations in the U.N. System. Washington, DC: Brookings Institution. 